\title{
DETERMINANTS OF PROFITABILITY OF ISLAMIC BANKS OF PAKISTAN - A CASE STUDY ON PAKISTAN'S ISLAMIC BANKING SECTOR
}

\author{
Muhammd Asadullah \\ Institute of Business Management , Karachi - Pakistan \\ E-mail : m.asadullah@iobm.edu.pk
}

\begin{abstract}
The purpose of this study is to find out the determinants of Islamic banks of Pakistan. The author collected data of five Islamic banks of Pakistan over ten years extending from 2006-2015. The independent variables were GDP, Size, Inflation \& Liquidity whereas dependent variables were Return on Asset. By using STATA software and employed panel regression, the researcher found that in fixed model effect, there are two significant variables at $5 \%$ i.e., size of Islamic banks and liquidity. Liquidity has positive whereas size has negative impact on profitability of Islamic banks. The findings will be helpful for Islamic banking sector to make their policies accordingly.
\end{abstract}

Keywords: Islamic Banks, Size, GDP, Inflation, Liquidity, Return On Assets

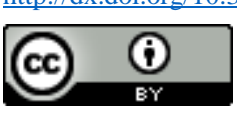

OPEN ACCESS

2523-6547 - Copyright: (C) 2017 The Authors. This is an open access article distributed under the terms of the Creative Commons Attribution License, which permits unrestricted use, distribution, and reproduction in any medium, provided the original author and source are credited. 


\section{Introduction}

Banks are playing vital role in our society, and it is impossible to imagine a life without banking. In other words, banks are supposed to be oxygen of an economy. Government of any country strengthens their economy through "Monetary Tools" via banking system. Furthermore, all financial and individual business transactions that we are being involved in are done through banks. In spite of advantages of conventional banking, disadvantages have also come out from it. As we noticed, financial and economic crisis of twenty first century has occurred mainly due to conventional banking system. The frequency of such financial crisis has been started due to existence of Capitalism where interest rate is allowed. If any individual fails to pay profit on debt, then it will affect whole system. In result, the economic system will may collapse therefore we had observed that due to economic crisis, the main victims were financial institutions i.e. commercial banks where conventional mode of financing and investments exist. Because of above reason, researchers, top managers, decision makers were keen to employ such policies which will not result into bankruptcy. Islamic bank models are one those model which will help to get rid of "interest" and consequences of its non-payment. All tools of Islamic banks are according to Shariah mode of financing which is interest free.

Even though, Islamic banking in Pakistan has been started for thirty years, but the serious efforts have been taken by State Bank of Pakistan in January 2000 when SBP established a (CTFS) on 15 September 2003, when SBP established the Islamic Banking Department. It was established by SBP to promote and introduce modes of Islamic financing and investments. In January 2002, Meezan Bank Limited was permitted as first Islamic Bank which was certify by the SBP to work as completely fledged Islamic bank in Pakistan.

The objective of this study is to study the impact of financial and macroeconomic determinants of Islamic banks in Pakistan on bank's profitability. Sadaqat, Akhtar and Ali (2011) found that the globally Pakistan's financial sector is among the most unstable market. SBP report stated that the total deposits of Islamic Banks were Rs 1.070 trillion in 2014 whereas the it was stood at Rs 868 billion in 2013. According to Economic Survey, the deposits of the Islamic Banks of Pakistan reached to Rs 1.4 trillion in 2015 \& expected to reach Rs 4 trillion by 2020. The research findings will be helpful for banking sector to understand the determinants of profitability closely and set their policies accordingly. Also, it will be helpful for investors, debtors, creditors and other business individuals to evaluate the risk of their investment in both sectors of banking in Pakistan.

In last few years, it has been observed that people are interested in financing and investing in Islamic modes of financing and investment. They are keen to get rid of interest in any way therefore other conventional banks are also opening their Islamic windows in order to retain and increase their market share.

\section{Theoretical Background: Inflation:}

\section{Literature Review}

According to the theory of Perry (1992), Islamic banks could not predict the inflation and therefore the it has reduced its profitability. It is easily understood that if inflation increases than consumer will consumed more and save less therefore deposits will decline. In result, the profitability of banks decreases.

Size:

Economic theory explained that if an industry is subjected to economies of scale, the institution will produce in less effective cost therefore it is expected that if size increases, profitability increases. It is other discussion that more than optimal limit of production, profitability decreases and costs (expenses) increases.

GDP:

According to Francis (n.d.), increase in growth will result in increment of profitability of Islamic banks. It is easily understandable that if economy produce more goods and services than there will be excess inflow of cash in the market which will be deposits in banks through which they earn more profit through Shariah mode of investments.

\section{Liquidity:}

A negative relationship has suggested by Francis (n.d.) that lesser liquidity increases banks' profitability. 


\section{Previous Studies: \\ Size of the firm:}

Abbas et al (2016) computes various elements of performance, including efficiency and effectiveness, and finds out the factors of variation in each component of performance by using the Tobit regression. The author found that size has positive and inflation has negative relationship with profitability of Islamic banks. Kashif et al (2016) Size, deposits, financing, share, GDP and Inflation are the factors that are insignificantly affect over ROA and ROE. Size, financing and market share positively impact over ROA and ROE whereas Deposits, GDP and Inflation negatively impact over ROA and ROE.

Asma et al (2011) found that only the bank's size has a positive significant impact on profitability of Malaysian Islamic banks. Haron (2004) found that liquidity \& size of the bank have a positive and significant impact on profitability of Islamic Banks. Al-Tamimi (2005). the study concluded that bank size has significant relation with ROA. Srairi (2009) found size has a positive relationship with profitability of conventional banks and Islamic banks.

Sehrish et al (2011) found that only ROA has positive insignificant relationship with the size of the firm. Pasiouras et al (2007) has found positive relationship between bank size and profitability. Bashir (2003) found that size has negative impact on the profitability of banks. Wasiuzzaman and Ahmed Tarmizi (2010) did not find a significant relationship between size and profitability of banks.

GDP:

Scott and Arias (2011) found that GDP has positive relationship with profitability of banks. Sufian (2011) found that the impact of GDP on ROA is mixed. It was found that the coefficient of GDP was negative, but it becomes positive when we have power over for both the crisis and calm periods. Khrawish (2011) found that there is a negative impact of GDP and inflation with ROA and ROE. Evans Ovamba (2014) analyzed the effect of macroeconomic variables on commercial banks profitability in Kenya. It was the case study of Equity Bank Limited. The estimated result showed that GDP has positive insignificant effect on profitability. Sehrish Gul et al (2011) found that (GDP) has positive relationship with ROA. Dietrich et al (2009) found positive relationship between GDP and profitability of banks.

Liquidity:

Guru \& Eichengreen and Gibson (2001), Bourke, (1989), Bashir, (2000). Liquidity is one of the important determinants of bank profitability. According to Eichengreen and Gibson (2001), The higher profitability could be expected if we tied up less funds in liquid investments. Haron (2004) that liquidity has positive relationship with the profitability of Islamic banks. Bourke (1989) found positive relationship between liquid assets and bank profitability. Molyneux et al (1992) found evidence of negative relationship between liquidity and profitability of banks. Asma et al (2011) found that there is no relationship between liquidity and profitability of the Malaysian banks.

\section{Inflation:}

Driver et al (2009) Inflation affects companies' pricing behavior. Sehrish Gul et al (2011) inflation (INF) shows the direct relationship with ROA. Saksonova and Solovjova (2011) authors concluded that Inflation (INF) had negative relationship with profitability (ROA). Waseem et al (2014)There is a positive relationship between Inflation and Profitability of banks. Alfani et al (2013) found that inflation does not have a significant impact to the banking profitability. Scott et al (2014) The empirical analysis indicated that Inflation and bank size of Nigeria observed to have had insignificant impact on banks' profitability in the study period. Mahmood et al (2014) tries to assess factors that affect the profitability of Islamic banking industry over the period of 2007 to 2014. Findings of the study indicate that measures of Islamic banking profitability are significantly affected Inflation. 


\section{Research Hypotheses:}

Null Hypothesis 1: GDP has no impact on profitability of Islamic Banks.

Null Hypothesis 3: Size of the bank has no impact on profitability of Islamic Banks.

Null Hypothesis 3: Liquidity of the bank has no impact on profitability of Islamic Banks.

Null Hypothesis 4: Inflation has no impact on profitability of Islamic banks.

\section{Research Design:}

\section{Methodology}

The research design of this study is descriptive. The panel data of five Islamic banks over a period of ten years, i.e. 2006-2015 are taken from their financial statements. The panel data regression method used by the researchers in order to find out the impact of macroeconomic and financial indicators on the profitability of Islamic banks of Pakistan.

\section{Survey Population:}

There are five Islamic banks in Pakistan, which are working under Shariah Compliant mode, taken as sample.

\section{Conceptual Framework:}

The Islamic bank model equation has been developed for this study. All variables i.e. financial and macroeconomic variables are supported by relevant theories and previous studies. The equation of model is as below:

\section{Equation:}

$\mathrm{PF}=\mathrm{Bo}+\mathrm{B} 1 \mathrm{GDP}+\mathrm{B} 2 \mathrm{INF}+\mathrm{B} 3 \mathrm{LQ}+\mathrm{B} 4 \mathrm{SZ}+\sigma$

Where, $\mathrm{PF}=$ Profitability of Islamic banks

GDP $=$ Gross Domestic Product

$\mathrm{INF}=$ Inflation

$\mathrm{SZ}=$ Size of Islamic banks

$\mathrm{LQ}=$ Liquidity of Islamic banks

$\sigma=$ Error Term

\section{Variables:}

The author has chosen those variables which are mostly found significant in previous researchers and they are also supported by relevant theories which are included in the literature review.

\section{Dependent Variable:}

The author selects profitability as the dependent variable. There are various variables which may represent profitability of the firm but the researcher has selected ROA ratio as the dependent variable.

(a) ROA:

ROA stands for Return on Assets. It is calculated by dividing the net income over total assets. ROA have been taken mostly as profitability measurement from the banks. It helps to find out the efficiency of any organization in a way that how much income they earn or generate from their assets. 
Table 1: Dependent Variable and their Assessment.

\begin{tabular}{|lll} 
Variable & Variable Name & Assessment \\
\hline ROA & Return On Assets & Net Income/Total Assets \\
\hline
\end{tabular}

\section{Independent Variables:}

The researcher has selected four independent variables in which two are financial and two are macroeconomic variables. The details of each independent are given below:

(a) GDP: (b)Inflation:

GDP stands for Gross Domestic Product. Total production and services over specified fiscal period. (c) Size:

The rate at which prices are rises and purchasing power decreases.

Size of the bank can be defined as the total assets of the firm. Assets are the most important tool through which any firm could generate more profit. It is not assumed that if any firm has more assets than other so they can earn more profit. Policies and strategies are also playing important role.

(d) Liquidity

The liquidity of any firm is the ability to fulfill all due liabilities in a time. The author uses Total loans to deposit ratio as liquidity variable.

Table 2: Independent Variables \& Their Assessments.

\begin{tabular}{|c|c|c|c|}
\hline Variables & Variables Name & Assessment & $\begin{array}{l}\text { Hypothesized } \\
\text { relationship with } \\
\text { profitability }\end{array}$ \\
\hline LIQ & Liquidity & $\begin{array}{l}\text { Total Loans/Total } \\
\text { Deposits }\end{array}$ & $+/-$ \\
\hline SZ & Size of the Bank & Total Assets & $+/-$ \\
\hline INF & Inflation & CPI & $+/-$ \\
\hline GDP & $\begin{array}{l}\text { Real Gross Domestic } \\
\text { Product }\end{array}$ & $\begin{array}{l}\text { Annual Growth Rate of } \\
\text { Economy }\end{array}$ & $+/-$ \\
\hline
\end{tabular}

\section{Transformation of Variables:}

The author has used log log variable transformation equation in order to fulfill assumption of panel regression analysis. It is one of the important remedy to get rid of heteroscedasticity issue in the data of panel analysis. If we do not remove autocorrelation and heteroscedasticity from the data, which we analyzed, then the results will not have supposed to be valid therefore it is necessary for the researcher to remove these issues before running panel regression analysis. The equation of both models will be as below:

(a) For Islamic Banks:

$(\log ) P F=B o+B 1(\log ) G D P+B 2(\log ) I N F+B 3(\log ) L Q+B 4(\log ) S Z+\sigma$

\section{Instruments for Data Collection:}

These are the methodologies used to identify data, information sources and collect information during the evaluation. The data of financial and economic variables (dependent and independent variables) are collected from secondary sources which include State Bank of Pakistan Reports, published Final Reports or financial 
statements of banks on their websites, Pakistan Statistics Bureau reports and Economic Survey of Pakistan reports. The author collects data from secondary sources via hard copies of reports of various sources and soft copy of them on their respective websites.

\section{Statistical Plan:}

We have financial and macroeconomic data in this study therefore we have set of panel data. The most suitable statistical tool is Panel Regression. The software which is used in this study is "STATA". Through panel regression, the author will be enable to choose the best suitable model among Fixed effect, Random Effect and OLS. Hausman Test was employed by the researcher, which is helpful to determine the better model among Fixed Effect Model and Random Effect Model. Due to characteristics of panel data regression, the author will have transformed the equation in order to remove autocorrelation and Heteroscedasticity from the data which otherwise give spurious results. Robust Error command was also used to minimize standard error which will be helpful to get valid findings.

\section{Results}

\section{Panel Test for Islamic Banks:}

The author employed STATA software to run panel regression. STATA is most powerful tool for panel data analysis. First, the author has developed panel setting for fixed and random effects models which are shown as below:

\section{Fixed Effect Model Results for Islamic Banks:}

The result of fixed model effect is as below:

Table \# 3: Fixed Effect for Islamic Banks

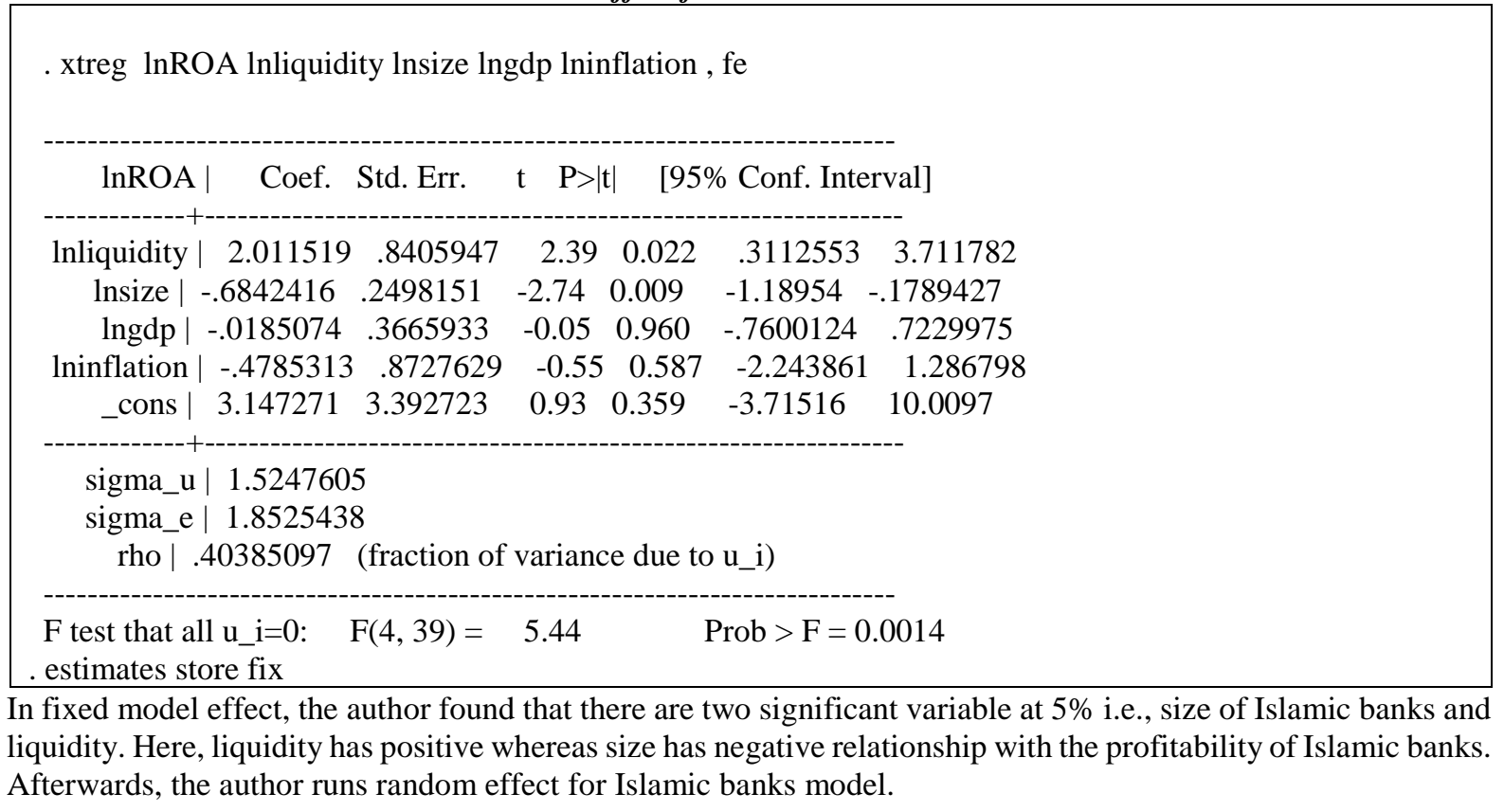

Random Effect Model Results for Islamic Banks:

After Fixed Effect Model, the researcher run the random effect model results for Islamic banks. The results are as below: 
. xtreg lnROA lnliquidity lnsize lngdp lninflation, re

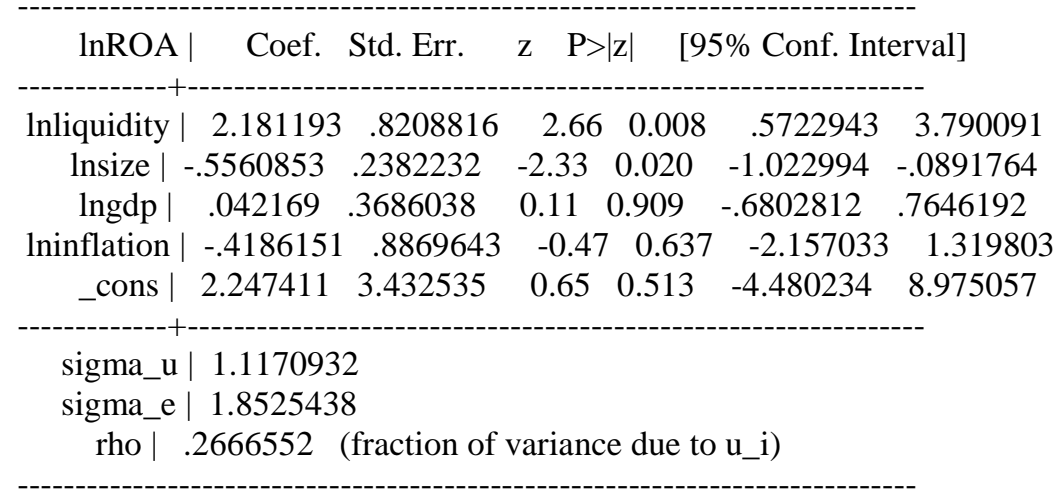

. estimates store ran

In random effect model, the author again found that liquidity and size are significantly associated with the profitability of Islamic banks. Both variables are significant at $5 \%$. Liquidity has a positive whereas size has a negative relationship. It is important to select suitable model by applying Hausman Test. The author has used the same test to select appropriate model among both of them.

Hausman Test:

It is used to select the most appropriate or fit model among random and fixed effect models.

Table \# 5: Hausman testing for selection of Random and Fixed Effect Model 
hausman fix ran

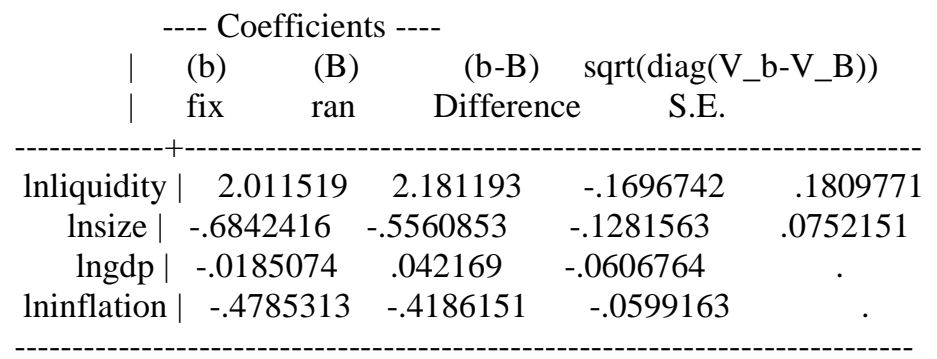

$$
\begin{gathered}
\mathrm{b}=\text { consistent under Ho and Ha; obtained from xtreg } \\
\mathrm{B}=\text { inconsistent under Ha, efficient under Ho; obtained from xtreg }
\end{gathered}
$$

Test: Ho: difference in coefficients not systematic

$$
\begin{aligned}
& \operatorname{chi} 2(4)=(b-B){ }^{\prime}\left[\left(V_{-} b-V \_B\right)^{\wedge}(-1)\right](b-B) \\
& =218.30 \\
& \text { Prob }>\text { chi } 2=0.0000 \\
& \left(V_{-} \text {b-V_B is not positive definite }\right)
\end{aligned}
$$

The P-value is less than 0.05 which suggests that fixed model is more suitable than random effect model.

Testing for cross-sectional dependence/contemporaneous correlation: Using Breusch-Pagan LM test of independence

The null hypothesis in the B-P/LM test of independence is that residuals across entities are not correlated.

Table \# 6 Breusch-Pagan LM test of independence

. xttest2

Correlation matrix of residuals:

$\begin{array}{rrrrrr} & -\mathrm{e} 0 & \mathrm{e} 1 & \mathrm{e} 2 & \mathrm{e} 3 & -\mathrm{e} 4 \\ \text { _e0 } & 1.0000 & & & & \\ \text {-e1 } & 0.1494 & 1.0000 & & & \\ \text { _e2 } & -0.4308 & -0.3027 & 1.0000 & & \\ \text { _e3 } & -0.2110 & -0.3814 & 0.2449 & 1.0000 & \\ \text { _e4 } & -0.1708 & -0.5662 & 0.5649 & -0.0021 & 1.0000\end{array}$

Breusch-Pagan LM test of independence: $\operatorname{chi} 2(10)=9.748, \operatorname{Pr}=0.4629$

Based on 8 complete observations over panel units

$\mathrm{P}-$ value 0.4629 gives the evidence that, there was no Cross-sectional Dependence in our model.

\section{Wald Test for Group wise Heteroscedasticity:}

It is important to check the validity of results therefore the author decided to check hetroskedasticity existence through modified Wald test for group wise hetroskedasticity which is used for fixed effect regression model. 
Table \#7: Wald Test for Group wise Hetroskedasticity

. xttest3

Modified Wald test for group wise heteroskedasticity in fixed effect regression model

H0: $\operatorname{sigma}(i)^{\wedge} 2=\operatorname{sigma}^{\wedge} 2$ for all $\mathrm{i}$

$\operatorname{chi} 2(5)=6.72$

Prob $>$ chi $2=0.2420$

Insignificant value of test gives the evidence that, there was no problem of heteroskedasticity in our data.

\section{Testing for Serial Correlation:}

Serial correlation is another important issue in panel data estimation. The existence of serial correlation may endorse regression results spurious.

\section{Table \#8: Wooldridge Test for Autocorrelation}

. xtserial $\ln R O A$ lnliquidity lnsize lngdp lninflation

Wooldridge test for autocorrelation in panel data

H0: no first-order autocorrelation

$$
\begin{array}{cc}
\mathrm{F}(1, \quad 4)= & 0.539 \\
\text { Prob }>\mathrm{F}= & 0.5036
\end{array}
$$

Test value suggested that, there was no problem of Serial correlation in the designed model. Therefore, we can say that results are valid as it does not contain any issue of hetroskedasticity, Serial correlation and cross sectional dependence in Islamic banks model.

\section{Conclusion \& Discussion}

In Table 3 the author has found that there are only two variables which are significantly associated with the profitability of Islamic banks of Pakistan i.e. liquidity and size of the bank. Liquidity has positive coefficient i.e. 2.01, therefore the researcher concluded that liquidity has a positive and significant relationship with the profitability of Islamic banks. It means a one percent increase in liquidity will lead to increase the level of profit by $2.01 \%$. Result are inconsistent by Economy Theory of size of the firm and Francis (n.d) theory for liquidity. The result of the relationship between liquidity and profitability is inconsistent with the study of Eichengreen and Gibson (2001), Bourke (1989), Molyneux et al (1992) \& Goddard et al (2004). The result of liquidity is consistent with the findings of Haron (2004) \& Asma et al (2011)

Islamic banks are younger than conventional banks therefore they may set their liquidity management more effective because initially financial institutions started to introduce short term financing options in order to full fill short term liabilities and cash obligations. More liabilities wiped out the portion of profitability of any organization because they have to pay interest and principal amount monthly or periodically. It is very rare skill among financial institution in Pakistan to get benefit from liabilities by implementing feasible plans which will be helpful to earn an excess amount to repay debt installments easily and retain remaining portion of income. 
In Pakistan, Islamic banks are adopting less risky policies and issuing short term loans which are also less profitable than issuing long term loans. These short term loans are the important determinant of profitability for Islamic banks of Pakistan.

Table 3 also shows that the size of the bank has a significant and negative impact on profitability of the Islamic banks of Pakistan. The significant and negative impact of size on the profitability is consistent with the research findings of Wasiuzzaman and Ahmed Tarmizi (2010) \& Bashir (2003). The result are inconsistent with the study findings of Pasiouras et al (2007), Al-Tamimi (2005), Srairi (2009) \& Athanasaglou et al (2005).

The size of the bank has positive coefficient i.e. -0.68 therefore the researcher concluded that the it has a negative and significant relationship with the profitability of Islamic banks. It means a one percent increase in size of the bank will cause the level of profit to be decreased by -0.68 percent.

Large organizations have more areas to produce income rather than an organization of small size. Islamic banks are smaller than conventional banks that's why the profitability of conventional banks is higher than Islamic banks in terms of size. Islamic banks need to develop their financing tools according to their size which is increasing rapidly.

Other two variables, Gross Domestic Product (GDP) and Inflation (INF) are insignificant and have no impact on profitability of the Islamic banks. Francis (n.d) proposed different behavior of GDP with profitability of banks. As we know that, Islamic banking system has started their operations not more than a decade ago therefore we can say that they require more time at market to absorb the shocks of the economy. The economic crisis is irrelevant to newly established banks up to some extent because it is common in the initial stage that they are unable to shorten their payback period. Gross Domestic Product (GDP) have not been varied a lot in the last ten years, therefore we can say that Islamic banks have not faced any abnormal increase or decrease in GDP therefore it is insignificantly associated to their profitability. The insignificant relationship is consistent with the research conclusion of Sufian (2011) \& Evans Ovamba (2014).

Inflation (INF) is also insignificantly associated with profitability (ROA) of Islamic banks of Pakistan. Previous researches found the same results (Francis, 2012; Khrawish, 2011; Saksonova \& Solovjova, 2011; Sufian 2011). The researchers also believed that the economic system of Pakistan is still in under developed stage therefore the impact of macroeconomic variables on bank's profitability are not supported by existing theories. The functions of macroeconomic variables will show their true effects when once the economic system of country will be become developed, matured. and established.

\section{Recommendation for Future Researchers}

This research could be expanded by future researchers by analyzing the impact of financial and economic indicators on performance based rather than profitability based. Furthermore, the future researchers could include more variables to analyze their impact on profitability of the Islamic banking sector. They can also compare the impact of determinants of profitability of both sectors of banking i.e. Islamic banks and conventional banks. 


\section{References}

Al-Kassim, F. (2005), "The Profitability of Islamic and Conventional Banking in the GCC

Countries: A

Comparative Study”, 48-54.

Al-Tamimi, H. A. (2005). The Determinants of the UAE Commercial Banks' Performance:A Comparison of the National and Foreign Banks. Journal of Transnational Management, $\quad 10(4), 35-47$.

Athanasoglou, P.P., S.N. Brissmis and M.D. Delis, 2005. Bank-Specific, Industry-Specific and Macroeconomic Determinants of Bank Profitability. Working Paper, Bank of Greece .

Asma, I. F., Adli, A., \& Noor, T. (2011). Determinant of Islamic banking institutions’ profitability in Malaysia. Word Applied Sciences Journal, 12.

Bashir, A.H., 2003. Determinants of Profitability in Islamic Banks: Some Evidence from the Middle East. Islamic Economic Studies, 11(1): 31-57.

Bashir, A. (2000). Determinants of Profitability and Rates of Return Margins in Islamic Banks: Some Evidence from the Middle East, Grambling State University, Mimeo.

Bourke, P. , (1989), "Concentration and other Determinants of Bank Profitability in Europe". Journal of Banking and Finance, pp65-80.

Boyd and Champ, (n.d.) Inflation, Banking, and Economic Growth.

Choi, S., B. D. Smith, et al. (1996).’Inflation, Financial Markets, and Capital Formation.’Federal Reserve Bank of St. Louis Review.

Demirgüç-Kunt, A. and H. Huizinga (1999). Determinants of commercial bank interest margins and profitability: Some international evidence. The World Bank Economic Review 13.

Dietrich, A. \& Wanzenried, G. (2009). "What Determines the Profitability of Commercial Banks? New Evidence from Switzerland”. 12th Conference of the Swiss Society for Financial Market Researches, Geneva.

Driver, R. and R. Windram (2007). Public Attitudes to Inflation and Interest Rates. Bank of England, Quarterly Bulletin 47(2): 208-223.

Eichengreen, B. and H.D. Gibson (2001). "Greek banking at the dawn of the new millennium." CERP Discussion Paper 2791, London.

Goddard, J., Molyneux, P. \& J.O.S. Wilson (2004). "Dynamics of Growth and Profitability in Banking," Journal of Money, Credit and Banking 36, 1069-1090.

Gul, S., Irshad, F., \& Zaman, K. (2011), “Factors Affecting Bank Profitability in Pakistan”, The Romanian Economic Journal, Vol XIV, No. 39, 61- 83.

Haron, S., 2004. Determinants of Islamic Bank Profitability. Global Journal of Finance and Economics, 1 (1).

Khrawish, H. A. (2011). Determinants of commercial banks performance: evidence from Jordan. International Research Journal of Finance and Economics(81), 148-159.

Moore, B. J. (1986). ’Inflation and Financial Deepening.” Journal of Development Economics

20: 125-133.

Molyneux, P. \& J. Thornton (1992), "Determinants of European Bank Profitability: A Note," Journal of Banking and Finance, Vol. 16, No. 6, 1173-8.Naceur, S. B. (2003), "The Determinants of the Tunisian Banking Industry Profitability: Panel Evidence," Universite Libre de Tunis Working Papers. 
Pasiouras, F., Kosmidou, K. 2007. Factors influencing the profitability of domestic and foreign

commercial banks in the European Union. Research In International Business \& Finance 21(2), 222-237

Saksonova, S., \& Solovjova, I. (2011). Analysis Of The Quality And Profitability Of Assets In The Banking System And The Impact Of Macroeconomic Factors On Its Stability-Case Of Latvia.International Conference On Applied Economics, (pp. 537-548).

Sadaqat, M. S., Akhtar, M. F., \& Ali, K. (2011). An Analysis on the Performance of IPO - A Study on the Karachi Stock Exchange of Pakistan. "International Journal of Business and Social Science", 2(6), 275-285.

Scott, J. W., \& Arias, J. C. (2011). Banking profitability deteminants. Business Intelligence Journal, 4(2), 209-230

Srairi, S.A., 2009. Factors Influencing the Profitability of Conventional and Islamic Commercial Banks in GCC Countries. Review of Islamic Economics, 13(1): 5-30.

Sufian, F. and M. Habibullah, 2009. Bank Specific and Macroeconomic Determinants of Bank Profitability: Empirical Evidence from the China Banking Sector. Frontiers of Economics $\quad$ in China, 4(2): 274-291.

Sufian, F. (2011). Profitability Of The Korean Banking Sector: Panel Evidence On Bank- Specific And Macroeconomic Determinants. Journal of Economics and Management, 7(1), 43-72.

Wasiuzzaman, S., and H. Ahmed Tarmizi, 2010. Profitability of Islamic Banks in Malaysia: An Empirical Analysis. Journal of Islamic Economics, Banking and Finance, 6(4): 51-68. 

are credited. 